Article

\title{
In Vitro Propagation of Oriental White Oak Quercus aliena Blume
}

\author{
Qiansheng Li ${ }^{1}\left(\mathbb{D}\right.$, Mengmeng Gu ${ }^{1}\left(\mathbb{D}\right.$ and Min Deng ${ }^{2,3, *}$ \\ 1 Department of Horticultural Sciences, Texas A\&M AgriLife Extension Service, College Station, TX 77843, USA; \\ qianshengli@tamu.edu (Q.L.); mgu@tamu.edu (M.G.) \\ 2 Shanghai Chenshan Plant Science Research Center, Chinese Academy of Sciences, Shanghai 201602, China \\ 3 Southeast Asia Biodiversity Research Institute, Chinese Academy of Sciences, Menglun, \\ Mengla 666303, China \\ * Correspondence: dengmin@sibs.ac.cn
}

Received: 28 April 2019; Accepted: 23 May 2019; Published: 28 May 2019

check for updates

\begin{abstract}
Quercus aliena Blume, also known as the oriental white oak, is a widespread species in temperate forests of East Asia with significant ecological and economical importance. Establishing an efficient vegetative propagation system is important for its germplasm conservation and breeding program. Protocols of micropropagation from shoot tips and nodal segments were investigated in order to produce uniform high-quality seedlings. Nodal segments from 18 month old seedlings were used as explants to initiate the aseptic culture. The highest bud proliferation was achieved by subculturing the explants on $1 / 2$ strength woody plant medium (WPM) with $2.0 \mathrm{mg} \cdot \mathrm{L}^{-1} \mathrm{BA}$. WPM with $0.5 \mathrm{mg} \cdot \mathrm{L}^{-1} \mathrm{BA}$ and $0.05 \mathrm{mg} \cdot \mathrm{L}^{-1} \mathrm{IBA}$ was the best medium for subculture to obtain the vigorous regenerated shoots in this experiment. Nodal segments without shoot tips had a higher adventitious bud proliferation rate than those with shoot tips. The highest rate (41.5\%) of rooting in vitro was induced by using WPM with $1.0 \mathrm{mg} \cdot \mathrm{L}^{-1}$ IBA and $5 \mathrm{~g} \cdot \mathrm{L}^{-1}$ activated charcoal. Ex vitro rooting by dipping the proliferated shoots with $500 \mathrm{mg} \cdot \mathrm{L}^{-1}$ IBA solution, then transplanting directly to potting mix with $50 \%$ peat and $50 \%$ horticultural perlite fostered the highest rooting percentage and survival rate of the plantlets.
\end{abstract}

Keywords: ex vitro rooting; micropropagation; Quercus aliena; tissue culture; vegetative propagation

\section{Introduction}

Quercus aliena Blume, commonly known as oriental white oak, is widespread deciduous oak from section Quercus of the family Fagaceae. It grows up to 30 meters tall with fissured grey-brown bark. It is widespread in the mixed mesophytic forests of China, Japan and Korea at elevations ranging from 100-2700 $\mathrm{m}$. There are two varieties recognized under the species, including Q. aliena var. acutiserrata and Q. aliena var. pekingensis [1,2]. It is an important relict vegetation of temperate forests and culturally important sites. It is an instantly recognizable facet of Korean heritage [3], and an important forestry species in Northern China [4] commonly used as landscape trees [5]. Its wood is a good material for building boats, furniture and wood flooring for houses. In addition, the wood waste of oriental white oak can be pyrolyzed in a fluidized bed reactor to produce bio-oil [6]. As one of the most common deciduous trees in East Asia, its acorns support the fundamental food chains in the forest ecosystems [7]. Meanwhile, the starch of $Q$. aliena acorns was historically cooked as food by human around 10,000 years ago [8]. Recent studies indicated that aqueous extracts of $Q$. aliena acorn had higher superoxide radical scavenging activity, and had protective effect against $\mathrm{CCl}_{4}$-induced hepatotoxicity in rats [9], which have a potential to be used as medicinal food. 
In oak seedling production, nurseries typically try to attain uniform high-quality seedlings to facilitate handling, shipping and planting procedures [10]. However, many factors influence the homogeneity and quality of seed germination and seedling establishment. Acorn size and mass significantly affect the seedling height, root collar diameter, and survival rate [11,12]. The infestation of weevils severely decreases the seed germination and seedling growth [13]. Seedlings from weevil-damaged acorns are likely to be less competitive in the forest [14]. Likewise, Q. aliena maximizes its viability through satiating larval feeding via annual variation in acorn sizes as a unique evolutionary mechanism to resist predators at seed level [15]. This mechanical restriction of the pericarp causes delayed and uneven germination, which adversely impacts the quality of its seedlings [2] and nursery production.

On the other hand, oaks are notorious for frequent interspecific hybridization, especially among the systematically closely-related species. For example, $Q$. aliena and $Q$. dentata are sympatrically distributed in a wide range in warm temperate forests of East Asia. The two species overlap at flowering time, which facilitates the introgression and hybridization between the two species [4]. A chloroplast DNA polymorphism study in four oak species (Q. serrata, Q. mongolica var. crispula, Q. dentata and Q. aliena) indicated that there has been previous gene flow among them, and the hybridization still occurs quite frequently [16]. The extensive interspecific hybridization and introgression in oak species might increase genetic diversity, but on the other hand, might reduce the species' genetic distinctiveness or lead to outcrossing depression, which can jeopardize the forest health and sustainable usage. Meanwhile, the hybridization can also boost phenotype diversity in the hybridized offspring and add an extra difficulty to forest management. In addition, the detection of hybridized offspring and pure species in oaks is still a pronounced difficulty, especially at the juvenile stage, which causes many problems regarding quality control in nursery-propagated trees [17]. Vegetative propagation has the advantage of producing uniform clones of superior genotypes for landscape use. Although there are risks of long-term genetic diversity loss by large-scale clonal propagation, it has many benefits and the risks can be controlled [18].

However, it is very difficult to vegetatively propagate most oaks by cutting, and the rooting ability decreases significantly with the age of oak tree, though grafting, cutting back, and etiolation are usually adopted to improve rooting $[19,20]$. Micropropagation from shoot tips or nodal explants is an efficient way to produce uniform quality oak clones with desired traits and is helpful for further improvement through genetic transformation [21]. However, tissue culture of oak species, especially using mature-phase plant material, is still a challenge, often resulting in low growth and survival ratio [22].

Though WPM is most commonly used for the micropropagation of many Quercus species [23], the ratios and concentrations of plant growth regulators are greatly varied among the species, even on the different regional populations and genotypes of the same species. The objective of this study is to optimize tissue culture media for different stages of the micropropagation process (shoot regeneration, shoot proliferation, rooting), and to provide a practical and simple protocol for successful micropropagation of $Q$. aliena.

\section{Materials and Methods}

\subsection{Plant Material}

Mature acorns of Q. aliena were collected on September 25, 2011, at Badagongshan, Sangzhi County, Zhangjiajie, Hunan Province, China (29.669 N, 109.799 E, elevation 1890 m). Acorns were washed and surface disinfected by $10 \%$ commercial bleach solution (contains $0.5 \%$ sodium hypochlorite) for $15 \mathrm{~min}$, drained and kept in ziplock bags at $4{ }^{\circ} \mathrm{C}$. Then, the acorns were sown in 32-cell plug trays in November 2011. When the seedlings were about $15 \mathrm{~cm}$ in height, they were then transplanted in plastic pots $(21 \mathrm{~cm} \times 16 \mathrm{~cm} \times 18.5 \mathrm{~cm})$ with substrate mixed by $60 \%$ peat moss, $20 \%$ perlite and $20 \%$ vermiculite, and placed in a shaded greenhouse. The shoots of $10-20 \mathrm{~cm}$ in length from the second year's new growth were cut into single nodal segments in June 2013, and used as explants. 


\subsection{Culture Initiation}

Shoot tips and shoot segments with one node were used to initiate axenic culture establishment. The explants were disinfected by rinsing under running tap water for $1 \mathrm{~h}$, immersed and shaken in $70 \%$ ethanol for 30 seconds, soaked in $1 \mathrm{~g} \cdot \mathrm{L}^{-1} \mathrm{HgCl}_{2}$ (Sinopharm, Shanghai, China) solution with 3 drops of Tween 20 for $10 \mathrm{~min}$, and then followed by rinsing in sterile, distilled water for three times under aseptic condition. The disinfected one-node shoot segments were then placed on Lloyd \& McCown [24] Woody Plant Medium (WPM) with different salt and 6-Benzylaminopurine (BA) concentrations (Table 1). All the media contained $30 \mathrm{~g} \cdot \mathrm{L}^{-1}$ sucrose and $6 \mathrm{~g} \cdot \mathrm{L}^{-1}$ agar (gelling strength $900 \mathrm{~g} \cdot \mathrm{cm}^{-2}$ ) and were adjusted to $\mathrm{pH} 5.8$, then autoclaved at $121^{\circ} \mathrm{C}$ for $15 \mathrm{~min}$. All culture jars were kept in an environmentally controlled growth room at $25^{\circ} \mathrm{C}$ under a $16 \mathrm{~h}$ photoperiod of Photosynthetic Photon Flux Density (PPFD) $60 \mu \mathrm{mol} \cdot \mathrm{m}^{-2} \cdot \mathrm{s}^{-1}$ by white LED lamps (Zhejiang Yankon Group Co., Ltd., Zhejiang, China). Induction of shoot organogenesis was investigated and compared after 5 weeks of culture. All the media, plant growth regulators, tissue culture jars were provided by Shanghai Jiafeng Articles for Horticulture Co., Ltd, Shanghai, China.

\subsection{Subculture for Shoot Proliferation}

The first-generation in-vitro shoots from the same media were cut above the callus and inoculated onto WPM supplemented with different concentrations of BA $\left(0.1,0.5\right.$, and $\left.1.0 \mathrm{mg} \cdot \mathrm{L}^{-1}\right)$ and/or IBA $\left(0,0.01\right.$, and $\left.0.05 \mathrm{mg} \cdot \mathrm{L}^{-1}\right)$ for subculture (Table 2). Each jar was inoculated with 10 shoots for proliferation (Figure 1C). The culture jars were placed under LED lights for a $16 \mathrm{~h}$ photoperiod at PPFD $60 \mu \mathrm{mol} \cdot \mathrm{m}^{-2} \cdot \mathrm{s}^{-1}$. Each treatment had six replications (six jars) with a total of 60 explants. The polycarbonate (PC) plastic jars were $340 \mathrm{~mL}$. Subcultures were evaluated after 5 weeks, and the regenerated shoot number produced by each explant was observed and counted.

\subsection{Rooting and Acclimatization}

When the subculture adventitious shoots reached to $3-4 \mathrm{~cm}$ in height, for in vitro rooting experiment, the shoots were cut without callus and transferred to WPM with IBA (Indole-3-butyric acid; $0,0.5$, and $1.0 \mathrm{mg} \cdot \mathrm{L}^{-1}$ ), without or with $5 \mathrm{~g} \cdot \mathrm{L}^{-1}$ activated charcoal (AC). The shoots were incubated in culture jars for 6 weeks. Root formation was observed and measured. The plantlets were then removed from the jars, the media on the roots was gently washed away, and the plantlets were transplanted into a 32-cell plug tray (cell top diameter $6 \mathrm{~cm}$, height $11 \mathrm{~cm}$, cell volume $190 \mathrm{~cm}^{3}$ ) with potting mix consisting of $50 \%$ peat and $50 \%$ perlite.

For ex vitro rooting, the shoots from proliferation were taken out from the jars, dipped in a $500 \mathrm{mg} \cdot \mathrm{L}^{-1}$ IBA solution for 3 seconds, and transplanted in the tray directly. Trays with plantlets were kept in a low tunnel covered with plastic film in a shaded greenhouse with a maximum PPFD of $300 \mu \mathrm{mol} \cdot \mathrm{m}^{-2} \cdot \mathrm{s}^{-1}$, at a temperature between 15 to $32{ }^{\circ} \mathrm{C}$. After transplanting, all the trays were watered thoroughly and sprayed with fungicide $\left(1 \mathrm{~g} \cdot \mathrm{L}^{-1}\right.$ carbendazim solution, Sichuan Guoguang Agrochemical Co., Ltd, Chengdu, China). The plastic film was kept closed to maintain the relative air humidity above $90 \%$ during the first 10 days, and then the plastic film was rolled up at night, but opened partially during the daytime for five more days. After that, the plastic film was removed. The survival rates of plantlets were recorded 6 weeks after transplanting.

To compare the root characteristics of in vitro and ex vitro rooting seedlings, five seedlings in vitro rooting and five seedlings from ex vitro rooting were randomly sampled. Media were gently washed away from the roots and the entire root systems were spread out and photographed with a digital camera (Nikon D90, Nikon Corporation, Tokyo, Japan). The photographs were processed with GiA Roots software [25] to quantify the root characteristics, including average root diameter (width), root length (network length), root area (network surface area), root volume (network volume), maximum number of roots, median number of roots [26]. 


\subsection{Statistical Analysis}

Data were analyzed by one-way and two-way ANOVA using SPSS Statistics Software (IBM SPSS Statistics for Windows, Version 19.0. IBM Corp., Armonk, NY, USA) and means were separated using Duncan's new multiple range test or independent samples $T$ test for root characteristics.

\section{Results}

\subsection{Aseptic Establishment and Initiation Culture}

Most shoot tips were necrotic with browning, and those surviving shoot tips produced few buds (0.6-2 buds per explant). Calluses started to form at the base of nodal segments after 10 days of inoculation on $1 / 2$ strength WPM with $2.0 \mathrm{mg} \cdot \mathrm{L}^{-1}$ (Figure $1 \mathrm{~A}$ ). The first adventitious bud emerged from the internode of explant on WPM with $2.0 \mathrm{mg} \cdot \mathrm{L}^{-1} \mathrm{BA}$ after 15 days of inoculation, with an average of 3.3 buds induced per explant (Table 1). The new shoots elongated quickly. However, the explants on $2 / 3$ and $1 / 2$ strength WPM showed bud initiation after 50 days of inoculation. The media salt concentration showed significant effects on bud proliferation ratio per nodal segment explant with $2 / 3$ and $1 / 2$ strength WPM generating the most buds. Both the media salt concentration and BA concentration alone significantly affected bud induction rate; and higher salt concentration caused slender stems and etiolating foliage. Half strength WPM with $2.0 \mathrm{mg} \cdot \mathrm{L}^{-1}$ BA produced 7.4 new buds per nodal segment, and the regenerated shoots were more vigorous than other treatments with no hyperhydration (Figure 1B). This protocol is effective and efficient at budding initiation stage to produce initial shoots for further subculture for proliferation.

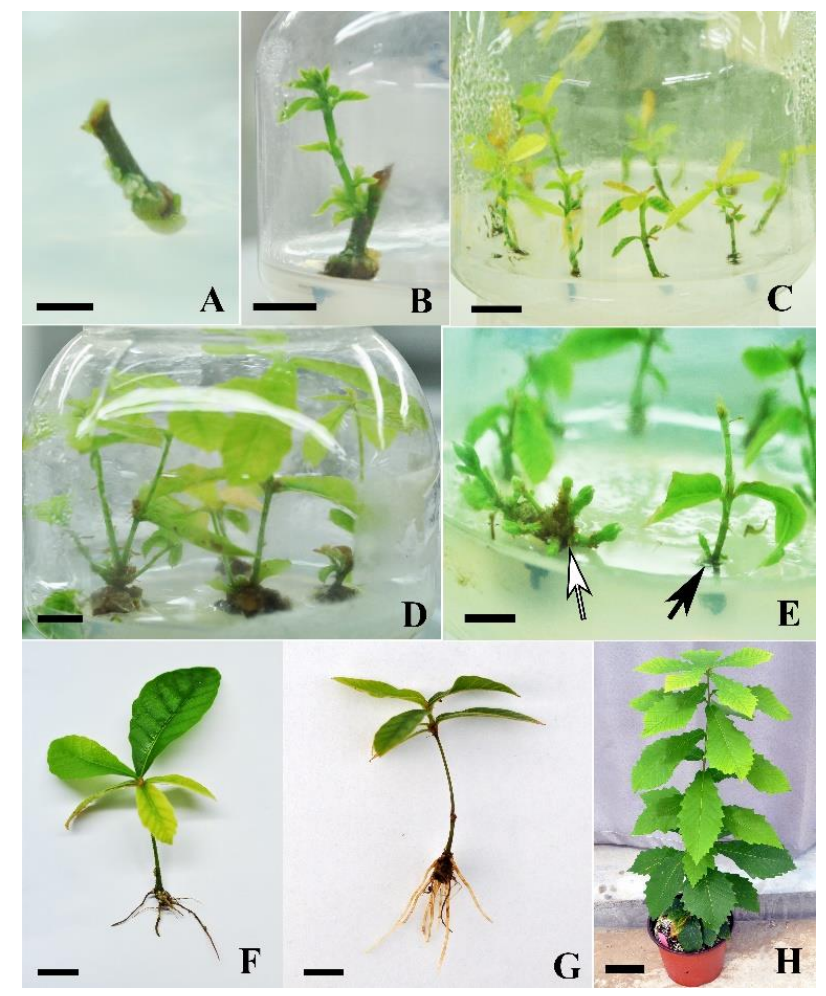

Figure 1. The micropropagation processes of Q. aliena. (A) callus formed at the base of shoot explant on the initiation medium $1 / 2$ strength WPM with $2.0 \mathrm{mg} \cdot \mathrm{L}^{-1} \mathrm{BA} ;(\mathbf{B})$ adventitious shoots developed on the initiation medium; (C) shoots on the subculture media; (D), shoot proliferation on subculture medium WPM with $0.5 \mathrm{mg} \cdot \mathrm{L}^{-1} \mathrm{BA}$ and $0.05 \mathrm{mg} \cdot \mathrm{L}^{-1} \mathrm{IBA}$; (E) Nodal segments without shoot tips proliferated more adventitious buds (open arrow) than the shoot tips (solid arrow); (F) the in vitro rooted plantlet; (G) the ex vitro rooted plantlet; (H) Plants reached $75 \mathrm{~cm}$ high 18 months after transplanted from ex vitro rooted plantlets into a $20 \mathrm{~cm}$ pot. All the bars represent $1 \mathrm{~cm}$, except the bar of $(\mathbf{H})$, which is $10 \mathrm{~cm}$. 
Table 1. Effects of media and BA concentration on in vitro establishment of Quercus aliena Blume.

\begin{tabular}{ccccc}
\hline Media & BA (mg. $\left.\mathbf{L}^{-\mathbf{1}}\right)$ & $\begin{array}{c}\text { Bud No. from } \\
\text { Shoot Tip }\end{array}$ & $\begin{array}{c}\text { Bud No. from } \\
\text { Nodal Segment }\end{array}$ & $\begin{array}{c}\text { Bud Induction Rate from } \\
\text { Nodal Segment (\%) }\end{array}$ \\
\hline WPM & 0.5 & $2.0 \pm 0.14 \mathrm{a}$ & $1.0 \pm 0.1 \mathrm{c}$ & $7.1 \% \pm 0.2 \mathrm{c}$ \\
WPM & 1.0 & $1.0 \pm 0.12 \mathrm{a}$ & $2.0 \pm 0.4 \mathrm{bc}$ & $14.3 \% \pm 0.5 \mathrm{~b}$ \\
WPM & 2.0 & $0.6 \pm 0.04 \mathrm{a}$ & $3.3 \pm 0.5 \mathrm{~b}$ & $23.8 \% \pm 0.3 \mathrm{~b}$ \\
2/3WPM & 2.0 & $1.0 \pm 0.09 \mathrm{a}$ & $6.0 \pm 0.2 \mathrm{a}$ & $42.8 \% \pm 0.2 \mathrm{a}$ \\
1/2WPM & 2.0 & $1.3 \pm 0.11 \mathrm{a}$ & $7.4 \pm 0.4 \mathrm{a}$ & $54.8 \% \pm 0.5 \mathrm{a}$ \\
\hline
\end{tabular}

Means $( \pm \mathrm{SE}, n=6)$ followed by the same letter within a column are not significantly different $(p \geq 0.05$, Duncan's multiple range test).

\subsection{Shoot Multiplication Stage}

The interaction between BA and IBA, and BA concentration alone significantly influenced the proliferation rate, but IBA had no significant impact (Table 2).

Table 2. Effects of BA and IBA concentrations on adventitious shoot proliferation on WPM media.

\begin{tabular}{cccc}
\hline BA $\left(\mathbf{m g} \cdot \mathbf{L}^{-\mathbf{1}}\right)$ & IBA $\left(\mathbf{m g} \cdot \mathbf{L}^{-\mathbf{1}}\right)$ & Shoot No. per Explant & Morphology of Adventitious Shoots and Explants \\
\hline 0.1 & 0 & $1.5 \pm 0.1 \mathrm{~d}$ & very few loose calluses, but shoot growth is slow \\
0.1 & 0.01 & $1.8 \pm 0.2 \mathrm{~d}$ & loose callus \\
0.1 & 0.05 & $2.4 \pm 0.1 \mathrm{c}$ & some compact calluses \\
0.5 & 0 & $2.9 \pm 0.3 \mathrm{bc}$ & some loose calluses \\
0.5 & 0.01 & $2.6 \pm 0.3 \mathrm{c}$ & few loose calluses, narrow leaves \\
0.5 & 0.05 & $3.1 \pm 0.2 \mathrm{ab}$ & few loose calluses, stems sturdy, shoots grow fast \\
1.0 & 0 & $3.7 \pm 0.2 \mathrm{ab}$ & some loose calluses, more leaves, some hyperhydration \\
1.0 & 0.01 & $4.5 \pm 0.3 \mathrm{a}$ & mass loose calluses, shorter internode, some hyperhydration \\
1.0 & 0.05 & $4.3 \pm 0.2 \mathrm{a}$ & mass compact calluses, some rooted, more hyperhydration \\
\multicolumn{2}{c}{ Significance } & $* *$ & \\
\multicolumn{2}{c}{ BA } & $\mathrm{ns}$ & \\
IBA & $*$ & \\
\hline
\end{tabular}

Means $( \pm$ SE, $n=6)$ followed by the same letter within a column are not significantly different $(p \geq 0.05$, Duncan's multiple range test). ${ }^{* *}$ indicates significant, $p<0.01$; ${ }^{*}$ indicates significant, $p<0.05$; ns indicates not significant, $p \geq 0.05$.

Increasing BA concentration was associated with higher shoot proliferation rate, but $1.0 \mathrm{mg} \cdot \mathrm{L}^{-1}$ BA also induced more compact callus and hyperhydrated shoots. The WPM medium containing $0.5 \mathrm{mg} \cdot \mathrm{L}^{-1} \mathrm{BA}$ and $0.05 \mathrm{mg} \cdot \mathrm{L}^{-1}$ IBA regenerated 3.1 shoots per explant (Figure 1D), which was not the highest rate obtained from our study, but these new shoots grew more vigorously than those in other treatments, and without hyperhydration.

\subsection{Rooting Stage}

Neither the interaction between IBA and activated charcoal $($ IBA $\times$ AC) nor AC alone had significant influence on all the rooting percentages, average root number and survival rate (Table 3 ).

The rooting percentage was significantly improved when IBA concentration was increased from 0 to $1.0 \mathrm{mg} \cdot \mathrm{L}^{-1}$, and IBA had significant positive influence on the survival rate after transplanting. In this study, the WPM medium with $1.0 \mathrm{mg} \cdot \mathrm{L}^{-1} \mathrm{IBA}$ and $5 \mathrm{~g} \cdot \mathrm{L}^{-1}$ activated charcoal generated the best results ( $41.5 \%$ rooting and $76 \%$ transplanting survival rate). But the in vitro rooting percentage was still low, and those roots were brown, slender, weak and lacking vigor (Figure 1F). The ex vitro rooting, by transplanting proliferated shoots to soil after dipping with $500 \mathrm{mg} \cdot \mathrm{L}^{-1}$ IBA solution, increased the rooting percentage to $85 \%$, and the roots grew more vigorously with white root tips (Figure 1G). The root number, average root diameter, total root length, root area, and root volume were significantly increased (Table 4). The seedlings grew to $75 \mathrm{~cm}$ high in a $20 \mathrm{~cm}$ pot in greenhouse within eighteen months (Figure 1H). 
Table 3. Influence of different auxins concentration and activated charcoal on rooting and plantlet survival.

\begin{tabular}{|c|c|c|c|c|}
\hline IBA $\left(\mathrm{mg} \cdot \mathrm{L}^{-1}\right)$ & $\begin{array}{l}\text { Activated Charcoal } \\
\text { (AC, } 0.5 \%)\end{array}$ & $\begin{array}{c}\text { Rooting } \\
\text { Percentage (\%) }\end{array}$ & Average Root No. & $\begin{array}{l}\text { Survival Rate after } \\
\text { Transplanting (\%) }\end{array}$ \\
\hline 0 & yes & $14.5 \pm 0.8 c$ & $1.4 \pm 0.2 \mathrm{c}$ & $27 \pm 2.8 b$ \\
\hline 0.5 & yes & $25.5 \pm 2.1 b$ & $1.7 \pm 0.1 b$ & $55 \pm 3.5 b$ \\
\hline 1.0 & yes & $41.5 \pm 3.2 \mathrm{a}$ & $2.1 \pm 0.3 a$ & $76 \pm 4.5 a$ \\
\hline 0 & no & $16.3 \pm 2.3 c$ & $1.3 \pm 0.2 c$ & $15 \pm 1.7 c$ \\
\hline 0.5 & no & $21.1 \pm 1.9 b$ & $1.8 \pm 0.1 \mathrm{ab}$ & $28 \pm 3.6 c$ \\
\hline 1.0 & no & $28.6 \pm 2.1 b$ & $1.6 \pm 0.3 b$ & $43 \pm 3.8 b$ \\
\hline \multicolumn{5}{|c|}{ Significance } \\
\hline \multicolumn{2}{|r|}{ IBA } & * & ns & * \\
\hline \multicolumn{2}{|r|}{$\mathrm{AC}$} & ns & $\mathrm{ns}$ & ns \\
\hline \multicolumn{2}{|r|}{$\mathrm{IBA} \times \mathrm{AC}$} & ns & ns & ns \\
\hline
\end{tabular}

Means ( \pm SE, $n=6$ ) followed by the same letter within a column are not significantly different ( $p \geq 0.05$, Duncan's multiple range test). ${ }^{*}$ indicates significant, $p<0.05$; ns indicates not significant, $p \geq 0.05$.

Table 4. Root characteristics of shoots rooted in vitro and ex vitro.

\begin{tabular}{cccc}
\hline & Root In Vitro & Root Ex Vitro & Significance \\
\hline Average Root Diameter $(\mathrm{mm})$ & $0.33 \pm 0.02$ & $0.51 \pm 0.02$ & $* *$ \\
Total Root Length $(\mathrm{cm})$ & $9.60 \pm 0.27$ & $28.80 \pm 0.62$ & $* *$ \\
Root Area $\left(\mathrm{cm}^{2}\right)$ & $1.07 \pm 0.05$ & $4.48 \pm 0.20$ & $* *$ \\
Root Volume $\left(\mathrm{cm}^{3}\right)$ & $0.01 \pm 0.001$ & $0.06 \pm 0.001$ & $* *$ \\
Maximum No. of Roots & $5.60 \pm 0.51$ & $9.40 \pm 0.51$ & $* *$ \\
Median No. of Roots & $2.40 \pm 0.24$ & $4.80 \pm 0.37$ & $*$ \\
\hline
\end{tabular}

Means \pm SE $(n=5),{ }^{* *}$ indicates significant by $t$-test, $p<0.01$.

\section{Discussion}

Woody plant medium (WPM) is efficient for the micropropagation of most Quercus plants [23]. After preliminary trials, WPM was chosen as the basal medium for Q. aliena. A better result was achieved when the salt concentrations were reduced to $2 / 3$ and $1 / 2$ strength for the initiation culture in this study (Table 1). Media with low concentrations of ions were also more suitable for growth and proliferation of explants than the other media containing higher salts for Q. suber micropropagation [27]. Low salts could reduce the browning and improve the initial shoot establishment [28]. However, the aseptic new formed shoots should be transferred to full strength WPM soon after establishment to avoid nutrient deficiency.

The concentrations and ratio of auxin and cytokinin were the most critical factors that promoted shoot proliferation rate in this study. In micropropagation, exogenous cytokinin in culture medium releases buds from apical dominance both on initial shoot segments and subsequent lateral shoots [29]. And the exogenous plant growth regulators will affect the shoot proliferation along with the endogenous hormone synergistically. Thus, the best cytokinin and auxin concentrations and ratio will vary among the different species, ages of explants, cut position of explants, nutritional status, and culture conditions [30]. The effects of auxin and cytokinin concentration and ratio on shoot proliferation rate has been shown to be quite different for different genotypes of the same species [23]. In our study, some nodal segments without stem tips produced more adventitious buds (Figure 1E, indicated with open arrow), while the segments with shoot tips produced less adventitious buds (Figure 1E, indicated with solid arrow). This phenomenon is likely caused by the apical dominance. To achieve a higher proliferation rate, shoots could be cut into several nodal segments in the subculture.

The optimal concentrations of cytokinin varied considerably among different oak species micropropagation. In Q. serrata, WPM with $2 \mathrm{mg} \cdot \mathrm{L}^{-1} \mathrm{BA}$ produced the highest number of shoots [31]. While highest shoot proliferation rate of $Q$. ilex was achieved by alternating 2 week long subcultures on much lower concentration of cytokinin, which was $0.1 \mathrm{mg} \cdot \mathrm{L}^{-1}$ BA first, followed by $0.05 \mathrm{mg} \cdot \mathrm{L}^{-1}$ $\mathrm{BA}$, then $0.01 \mathrm{mg} \cdot \mathrm{L}^{-1} \mathrm{BA}$ plus $0.1 \mathrm{mg} \cdot \mathrm{L}^{-1}$ zeatin [32]. The effect of genotype on the optimal protocol 
was shown to be one of the most serious limitations concerning the commercial micropropagation of oaks [21]. Other components such as sucrose concentration and agar brand also affected shoot proliferation in $Q$. ilex [32]. Other basal media, such as plant growth regulators can also be trialed, however only BA and IBA were chosen in this study as these two plant growth regulators were the most commonly used.

The recalcitrance to rooting is a major problem in commercial micropropagation [33], especially in certain woody perennial species lacking the ability to form adventitious roots, especially in oaks. Many factors can affect the rooting capability, such as the juvenility of explants, auxin concentrations, and exudation of inhibitory compounds. Accumulation of ethylene during in vitro rooting may have devastating effect [33]. Activated charcoal is often used in tissue culture to improve rooting by adsorption of inhibitory compounds in the culture medium and substantially decreasing the toxic metabolites, phenolic exudation and brown exudate accumulation [34,35]. Activated charcoal could increase both the rooting percentages and secondary roots in Q. lusitanica [23]. However, in our case, activated charcoal did not significantly improve the rooting. Only IBA concentration did. Rooting percentage can be improved by using a combination of IBA and NAA in Q. suber [36]. In vitro rooting of $Q$. serrata was optimized by culture on WPM with very high IBA concentration $\left(20 \mathrm{mg} \cdot \mathrm{L}^{-1}\right)$ for only $48 \mathrm{~h}$, then were transferred to $1 / 2$ strength WPM without plant growth regulators [37]. In Q. leucotrichophora and Q. glauca, 90\% and 100\% rooting percentages were achieved with a 24-hour $20 \mathrm{mg} \cdot \mathrm{L}^{-1}$ IBA treatment, then transferred to $1 / 2$ strength WPM without plant growth regulators [38]. However, those protocols with short exposure to high concentration of rooting growth regulator are time and cost inefficient, labor intensive and could increase the risk of contamination.

Ex vitro rooting by direct transfer of the shoots from the multiplication medium to potting mix has been widely used in some difficult to root woody plants. This protocol was also tried as an alternative strategy in micropropagation of some oaks, such as Q. robur [39], Q. ilex [40], Q. suber [41]. Usually, ex vitro rooting resulted in a better rooting percentage, vigorously growing roots and increasing the survival rate. Comparatively, the plantlets rooted ex vitro were taller with more, and larger leaves than those in vitro rooted plantlets [42]. In our study, ex vitro plantlets showed larger and vigorous roots. Therefore, ex vitro rooting is a better time- and cost-efficient method by skipping the in vitro rooting stage.

New shoots from 18 months old seedling were used as explants in this study. Explants from young seedlings are relatively easy to establish initiation culture, while explants from mature trees are more challenging, as they tend to lose their regeneration potential [21,22]. Further trials are needed if some mature $Q$. aliena genotype with special traits need to be vegetative propagate for conservation or commercial production.

\section{Conclusions}

This study describes a simple, scientifically valid, practical and efficient micropropagation protocol for oriental white oak $Q$. aliena via proliferation of adventitious shoots, using only common and affordable plant growth regulators. Shoots from spring flush on young seedlings are efficient explants to establish in vitro culture. WPM at half strength with $2.0 \mathrm{mg} \cdot \mathrm{L}^{-1} \mathrm{BA}$ is optimal for initial inducing adventitious buds for further subculture of proliferation. WPM with $0.5 \mathrm{mg} \cdot \mathrm{L}^{-1} \mathrm{BA}$ and $0.05 \mathrm{mg} \cdot \mathrm{L}^{-1}$ IBA is the best combination for subculture to achieve vigorous shoot regeneration. The highest in vitro rooting rate $(41.5 \%)$ was obtained by WPM containing $1.0 \mathrm{mg} \cdot \mathrm{L}^{-1}$ IBA and $5 \mathrm{~g} \cdot \mathrm{L}^{-1}$ activated charcoal. Alternatively, ex vitro rooting by dipping the proliferated shoots with $500 \mathrm{mg} \cdot \mathrm{L}^{-1}$ IBA solution, then transplanting directly to potting mix with $50 \%$ peat and $50 \%$ perlite is also recommended for better rooting percentage and survival rate.

Author Contributions: Data curation, Q.L.; Formal analysis, Q.L.; Funding acquisition, M.D.; Investigation, Q.L. and M.D.; Project administration, M.D.; Supervision, M.G.; Writing—original draft, Q.L.; Writing-review \& editing, M.G. and M.D. 
Funding: This work is funded by Southeast Asia Biodiversity Research Institute, Chinese Academy of Sciences (Y4ZK111B01).

Acknowledgments: The authors are grateful to Hong Chen and Haiyan Zhou of the Ningbo Hesu Agricultural Science and Technology Co., Ltd., China, who provided facilities and constructive suggestions for this project.

Conflicts of Interest: The authors declare no conflict of interest.

\section{References}

1. Huang, C.C.; Chang, Y.T.; Bartholomew, B. Fagaceae. In Flora of China; Wu, C.Y., Raven, P.H., Eds.; Science Press: Beijing, China; Missouri Botanical Garden Press: St. Louis, MO, USA, 1999; Volume 4, pp. 370-380.

2. Liu, Y.; Liu, G.; LI, Q.; Liu, Y.; Hou, L.; LI, G. Influence of pericarp, cotyledon and inhibitory substances on sharp tooth oak (Quercus aliena var. acuteserrata) germination. PLoS ONE 2012, 7, e47682. [CrossRef] [PubMed]

3. Lee, S.-H.; You, Y.-H. Measurement of ecological niche of Quercus aliena and Q. serrata under environmental factors treatments and its meaning to ecological distribution. J. Ecol. Environ. 2012, 35, 227-234. [CrossRef]

4. Liu, Y.; LI, Y.; Song, J.; Zhang, R.; Yan, Y.; Wang, Y.; Du, F.K. Geometric morphometric analyses of leaf shapes in two sympatric Chinese oaks: Quercus dentata Thunberg and Quercus aliena Blume (Fagaceae). Ann. For. Sci. 2018, 75, 90. [CrossRef]

5. Whang, B.-C.; Lee, M.-W. Landscape ecology planning principles in Korean Feng-Shui, Bi-bo woodlands and ponds. Landsc. Ecol. Engin. 2006, 2, 147-162. [CrossRef]

6. Park, H.J.; Park, Y.-K.; Dong, J.-I.; Kim, J.-S.; Jeon, J.-K.; Kim, S.-S.; Kim, J.; Song, B.; Park, J.; Lee, K.-J. Pyrolysis characteristics of Oriental white oak: Kinetic study and fast pyrolysis in a fluidized bed with an improved reaction system. Fuel Proc. Technol. 2009, 90, 186-195. [CrossRef]

7. Chang, G.; Jin, T.; Pei, J.; Chen, X.; Zhang, B.; Shi, Z. Seed dispersal of three sympatric oak species by forest rodents in the Qinling Mountains, Central China. Plant Ecol. 2012, 213, 1633-1642. [CrossRef]

8. Yang, X.; Ma, Z.; Wang, T.; Perry, L.; Li, Q.; Huan, X.; Yu, J. Starch grain evidence reveals early pottery function cooking plant foods in North China. Chin. Sci. Bull. 2014, 59, 4352-4358. [CrossRef]

9. Jin, Y.-S.; Jin, Y.-S.; Heo, S.-I.; Jin, Y.-S.; Heo, S.-I.; Lee, M.-J.; Rhee, H.-I.; Wang, M.-H. Free radical scavenging and hepatoprotective actions of Quercus aliena acorn extract against $\mathrm{CCl}_{4}$-induced liver. Free radic. Res. 2005, 39, 1351-1358. [CrossRef]

10. Clark, S.; Schalarbaum, S.; Kormanik, P.P. Visual grading and quality of 1-0 northern red oak seedlings. South. J. Appl. For. 2000, 24, 93-97.

11. Kormanik, P.P.; Sung, S.; Kormanik, T.; Schlarbaum, S.; Zarnoch, S.J. Effect of acorn size on development of northern red oak 1-0 seedlings. Can. J. For. Res. 1998, 28, 1805-1813. [CrossRef]

12. Clark, S.L.; Schlarbaum, S.E. Effects of acorn size and mass on seedling quality of northern red oak (Quercus rubra). New For. 2018, 49, 571-583. [CrossRef]

13. Yu, F.; Shi, X.; Wang, D.; Yi, X.; Fan, D.; Guo, T.; Lou, Y. Effects of insect infestation on Quercus aliena var. acuteserrata acorn dispersal in the Qinling Mountains, China. New For. 2015, 46, 51-61.

14. Lombardo, J.A.; Mccarthy, B.C. Seed germination and seedling vigor of weevil-damaged acorns of red oak. Can. J. For. Res. 2009, 39, 1600-1605. [CrossRef]

15. Yi, X.; Yang, Y. Large acorns benefit seedling recruitment by satiating weevil larvae in Quercus aliena. Plant Ecol. 2010, 209, 291-300. [CrossRef]

16. Kanno, M.; Yokoyama, J.; Suyama, Y.; Ohyama, M.; Itoh, T.; Suzuki, M. Geographical distribution of two haplotypes of chloroplast DNA in four oak species (Quercus) in Japan. J. Plant Res. 2004, 117, 311-317. [CrossRef]

17. Oliveira, P.; Custódio, A.C.; Branco, C.; Reforço, I.; Rodrigues, F.; Varela, M.C.; Meierrose, C. Hybrids between cork oak and holm oak: Isoenzyme analysis. Int. J. For. Genet. 2003, 10, 283-298.

18. Wu, H.X. Benefits and risks of using clones in forestry-a review. Scand. J. For. Res. 2018, 1-8. [CrossRef]

19. Amissah, J.N.; Paolillo, D.J.; Bassuk, N. Adventitious root formation in stem cuttings of Quercus bicolor and Quercus macrocarpa and its relationship to stem anatomy. J. Am. Soc. Hortic. Sci. 2008, 133, 479-486. [CrossRef]

20. Amissah, J.N.; Bassuk, N. Cutting back stock plants promotes adventitious rooting of stems of Quercus bicolor and Quercus macrocarpa. J. Envir. Hortic. 2009, 27, 159-165. 
21. Vieitez, A.M.; Corredoira, E.; Martínez, M.T.; San-josé, M.C.; Sánchez, C.; Valladares, S.; Vidal, N.; Ballester, A. Application of biotechnological tools to Quercus improvement. Eur. J. For. Res. 2012, 131, 519-539. [CrossRef]

22. Brennan, A.N.; Pence, V.C.; Taylor, M.D.; Trader, B.W.; Westwood, M. Tissue Culture Using Mature Material for the Conservation of Oaks. HortTechnology 2017, 27, 644-649. [CrossRef]

23. San josé, M.; Martínez, M.; Cernadas, M.; Montenegro, R.; Mosteiro, F.; Corredoira, E. Biotechnological efforts for the propagation of Quercus lusitanica Lam., an endangered species. Trees 2017, 31, 1571-1581.

24. Lloyd, G.; McCown, B. Commercially-feasible micro-propagation of Mountain laurel, Kalmia latifolia, by use of shoot tip culture. Comb. Proc. Int. Plant Prop. Soc. 1980, 30, 421-427.

25. Galkovskyi, T.; Mileyko, Y.; Bucksch, A.; Moore, B.; Symonova, O.; Price, C.A.; Topp, C.N.; Iyer-Pascuzzi, A.S.; Zurek, P.R.; Fang, S. GiA Roots: Software for the high throughput analysis of plant root system architecture. BMC plant boil. 2012, 12, 116. [CrossRef]

26. Li, Q.; LI, X.; Tang, B.; Gu, M. Growth responses and root characteristics of lettuce grown in aeroponics, hydroponics, and substrate culture. Horticulturae 2018, 4, 35. [CrossRef]

27. Manzanera, J.; Pardos, J. Micropropagation of juvenile and adult Quercus suber L. Plant Cell Tissue Organ. Cult. 1990, 21, 1-8. [CrossRef]

28. Romano, A.; Louçao, M.M. Micropropagation of mature cork-oak (Quercus suber L.): Establishment problems. Sc. Gerund. 1992, 18, 17-27.

29. Razdan, M.K. Introduction to plant tissue culture; Science Publishers: Enfield, NH, USA, 2003.

30. Smith, R.H. Plant tissue culture: Techniques and experiments; Academic Press: Cambridge, MA, USA, 2012.

31. Pandey, A.; Sekar, K.C.; Tamta, S.; Rawal, R. Assessment of phytochemicals, antioxidant and antimutagenic activity in micropropagated plants of Quercus serrata, a high value tree species of Himalaya. Plant Biosyst. Int. J. Deal. Asp. Plant Biol. 2018, 152, 929-936. [CrossRef]

32. Martínez, M.T.; Corredoira, E.; Vieitez, A.M.; Cernadas, M.J.; Montenegro, R.; Ballester, A.; Vieitez, F.J.; San José, M.C. Micropropagation of mature Quercus ilex L. trees by axillary budding. Plant Cell Tissue Organ. Cult. 2017, 131, 499-512. [CrossRef]

33. De Klerk, G.-J. Rooting of microcuttings: Theory and practice. Vitr. Cell. Dev. Biol.-Plant 2002, 38, 415-422. [CrossRef]

34. Thomas, T.D. The role of activated charcoal in plant tissue culture. Biotechnol. Adv. 2008, 26, 618-631. [CrossRef]

35. Martínez, M.T.; Vieitez, A.M.; Corredoira, E. Improved secondary embryo production in Quercus alba and Q. rubra by activated charcoal, silver thiosulphate and sucrose: Influence of embryogenic explant used for subculture. Plant Cell Tissue Organ. Cult. 2015, 121, 531-546. [CrossRef]

36. Lebtahi, F.; Errahmani, M.B.; Bouguedoura, N. Propagation of cork oak (Quercus Suber, L.) by axillary shoot and somatic embryogenesis. Propag. Ornam. Plants 2015, 15, 113-122.

37. Pandey, A.; Tamta, S. In vitro propagation of the important tasar oak (Quercus serrata Thunb.) by casein hydrolysate promoted high frequency shoot proliferation. J. Sustain. For. 2014, 33, 590-603. [CrossRef]

38. Purohit, V.K.; Tamta, S.; Chandra, S.; Vyas, P.; Palni, L.M.S.; Nandi, S.K. In vitro multiplication of Quercus leucotrichophora and Q. glauca: Important Himalayan oaks. Plant Cell Tissue Organ. Cult. 2002, 69, 121-133. [CrossRef]

39. Meier-dinkel, A.; Becker, B.; Duckstein, D. Micropropagation and ex vitro rooting of several clones of late-flushing Quercus robur L. Ann. For. Sci. 1993, 50, 319-322. [CrossRef]

40. Liñán, J.; Cantos, M.; Troncoso, J.; García, J.L.; Fernández, A.; Troncoso, A. Some propagation methods for cloning holm oak (Quercus ilex L.) plants. Cent. Eur. J. Biol. 2011, 6, 359-364. [CrossRef]

41. Romano, A.; Martins-louçao, M. Strategies to improve rooting and acclimatization of cork oak. Acta Hortic. 2003, 616, 275-278. [CrossRef]

42. Oakes, A.D.; Desmarais, T.R.; Powell, W.A.; Maynard, C.A. Ex vitro rooting of American chestnut improves acclimatization survival and plantlet quality. J. Envir. Hortic. 2016, 34, 75-79.

(C) 2019 by the authors. Licensee MDPI, Basel, Switzerland. This article is an open access article distributed under the terms and conditions of the Creative Commons Attribution (CC BY) license (http://creativecommons.org/licenses/by/4.0/). 